\title{
AUDIOVISUAL STARTUPS - OPPORTUNITIES AND NEW BUSINESS MODELS
}

\author{
Chair: José Carlos Aronchi - SEBRAE-SP
}

The startups of cross-platform audiovisual bring disruptive and innovative solutions. Entrepreneurs, with shortened companies, gain market share and switch from content to low-tech, high-tech solutions. The panel presents innovations brought by audiovisual startups, indicates ways for the broadcasting industry through entrepreneurship and innovation and the support of the SET to stimulate the audiovisual startups ecosystem and its new business models.

\section{- STARTUPS NO MERCADO AUDIOVISUAL}

\section{Speaker: João Carlos Massarolo - UFSCar}

The Multiplatform Audiovisual Startups bring disruptive and innovative solutions. Entrepreneurs from lean companies gain market share from content to low-tech, high-tech solutions. In this panel we will talk about the training of the audiovisual professional to perform in multiplatforms, seeking to define an innovative and entrepreneurial profile, based on the experience acquired with the Graduate Program - Specialization Course in Audiovisual Content Production for Multiplatforms, at UFSCar.

- THE CAPTURE OF IMAGES BY DRONES AND THE POTENTIAL OF THE MARKET FOR STARTUPS

\section{Speaker: Raquel Molina - Diretora Executiva da Futuriste}

Futuriste is a pioneer startup in the use of drones capture in Brazil, which has expanded to services, training, maintenance, consulting and sales of customized drones to meet the needs of companies in various segments. Futuriste was the company with the highest number of nominations for the TOP3 DroneShow Brazilian Market. The presentation is about startup development, prototype, validation with clients, fundraising and investors, your business team and results. What is your business model and startup scalability projection. 
- UVIEW360 - INNOVATION STARTUP IN 360 IMAGES

Speaker: Charles Boggiss - CEO - UView360

Founded in 2010, the startup focused on 360-degree Video and live 360-degree video broadcasting, bringing innovation, interactivity and immersion to users. Acting in the most diverse sectors like Events, music clips, real estate projects, TV programs and more, UView360 is a case of virtual reality.

- SET INNOVATION ZONE: STARTUPS OF CROSS-PLATFORM AUDIOVISUAL GAINING BROADCAST AND BROADBAND MARKET Speaker: Edson Mackeenzy - Head SET Innovation Zone

The ecosystem of startups. What is. The profile of the entrepreneur, the team, the idea and modeling of the innovative business that goes out in search of the customer with MVP. Because startups are gaining market share. Where are the opportunities for audiovisual startups and broadcasters. The support of SET to the startups of the audiovisual. SIZ and the stimulus to startups in regional SET.

- GAMIFICATION CONTENT - GAMES STARTUPS ADVANCING ON SMART TVS AND MULTIPLATFORM Speaker: Fernando Chamis - Presidente da ABRAGAMES - Associação

\section{Brasileira dos Desenvolvedores de Jogos Digitais}

Paths to the startups of the gaming segment show a great business opportunity due to digital multiplatforms, such as smart tvs, and content with virtual reality and gamificados. ABRAGAMES, the Brazilian and international gaming market, cases of entrepreneurs that started as startup and now have national and international market results. ABRAGAMES support to stimulate game startups, with support from BNDES and APEX.

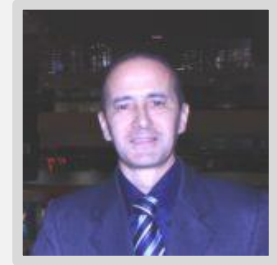

José Carlos Aronchi - SEBRAE-SP

SET Events Director. Consultant of Innovation and Technology in the Entrepreneurial Culture Unit - Business School of Sebrae-SP Alencar Burti. Journalist and broadcaster, MSc in Scientific and Technological Communication from Universidade Metodista / SP, doctorate in Communication Sciences from ECA / USP and postdoctoral fellow at UFSCar. Received at SET EXPO, in 2010, the Award for Best Innovation-Interactivity for Digital TV by the Roda dos Gêneros app from Digital TV. In 2016, he received the Sebrae Manager Award for Startups Like a Boss, at Campus Party SP. Mentor of companies startups of the audiovisual segment. He is a professor of the RTVi course at FacCamp / SP and a guest professor at UFSCar in the specialization course in Audiovisual Content Production for Multiplatforms. Author of "Genres and Formats in Brazilian Television" (2nd 
Edition) and "Be the first to know - CNN and the globalization of information". Member of GEMInIS - Study Group on Interactive Media in Image and Sound.

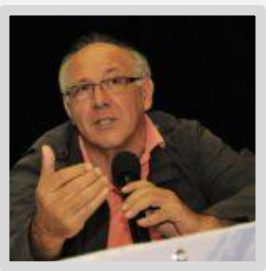

\section{João Carlos Massarolo - UFSCar}

João Carlos Massarolo: filmmaker, professor; PhD in Cinema by USP, is director and scriptwriter of several films, among which, São Carlos / 68 and O Quintal dos Guerrilheiros (2005). Published: Audiovisual script for Transmedia Storytelling (2016); Regarding the mediatization of transmedia fictional consumption and its effects (2015); Storytelling Transmedia: Narrative for multiplatforms (2014), among other papers. He is Associate Professor at UFSCar; Coordinator of the research group GEMInIS and Editor of the GEMInIS Journal. Email: massarolo@terra.com.br

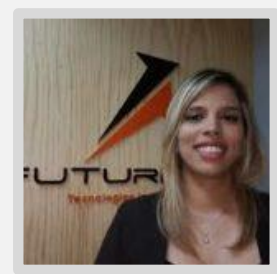

\section{Raquel Molina - Diretora Executiva da Futuriste}

Co-founder of Drones Futuriste Tecnologia, she is the company's executive director. She is considered the first woman instructor of Drones in Brazil, starting in the area in 2015. With a background in Technology, she has worked for several years as Systems Project Manager at major financial companies such as Itaú-Unibanco and Bradesco. Raquel holds a postgraduate degree in IT governance from Universidade Presbiteriana Mackenzie, an IT graduate with an Emphasis in Business Management from FATEC, Certified in ERP (Systems Requirements Engineering), certified in COBIT (IT Governance) and Technical Logistics by State Technical school.

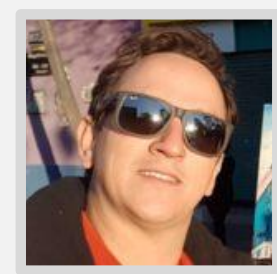

\section{Charles Boggiss - CEO - UView360}

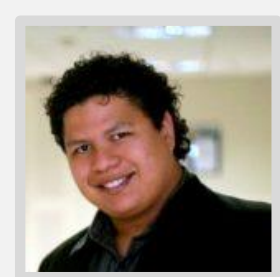

\section{Edson Mackeenzy - Head SET Innovation Zone}

Edson Mackeenzy, Experienced Entrepreneur, specialist in Innovation and Business Development. Radialist, Presenter, Facilitator and Keynote at Technology, Marketing and Business events. Mack is an important agent in the formation of Startups Ecosystems throughout Brazil and a link between them and the market. He is currently Head of Innovation at SET, Curator of the cooperative innovation platform Plataforma.Space for Sicoob. He acted as Dir. Of Relationship with Startups at Bossa Nova Investimentos, BizDev responsible for the LatAm expansion ofCodeFellows.org, executive producer of Relate Live by Zendesk, Head of Communication and Partnerships of the iMasters Group | E-CommerceBrasil, CEO and founder of the world's first video portal Videolog tv, Mentor, Facilitator and Community Leader at TechStars for actions like Startup Weekend. In 2015, he was named the best Startups Mentor in the country in the SparkAwards award of Microsoft, elected in 2013 one of the most influential entrepreneurs in Brazil, a member of RioSoft's board (agent Softex), involved in hundreds of conferences on communication, entrepreneurship, And business around the World. 


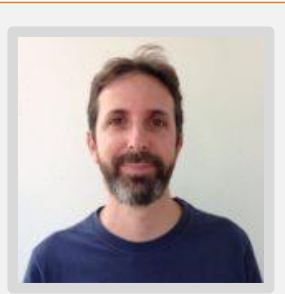

Fernando Chamis - Presidente da ABRAGAMES - Associação Brasileira dos Desenvolvedores de Jogos Digitais

Aronchi, J. C., Massarolo, J. C., Molina, R., Boggiss, C., Mackeenzy, E. and Chamis, F.; 2017. Audiovisual Startups - Opportunities and New Business Models. ISSN Print: 2447-0481. ISSN Online: 2447-049X. v.3. doi: 10.18580/setep.2017.7. Web Link: http://dx.doi.org/10.18580/setep.2017.7 